The need to establish conditions for safe irradiation was noted in Poland back in 1986 in the Atomic Law, but for over 16 years no regulations regarding this aspect were passed. The radiological incident in Bialystok (Poland) in 2001 undeniably accelerated the implementation of new legal regulations. Nevertheless, in the absence of national guidelines until 2002, most health care institutions resorted to the quality management system (QMS) model proposed by the ISO norm 9001:2000. Eventually, practice proved the theory and the aforementioned model was also implemented into Polish acts of law defining basic requirements for QMS in radiotherapy. The aim of this work is to review current national regulations regarding QMS in radiotherapy, in particular those referring to standard procedures, the establishment of a commission for procedures and performance of external and internal clinical audits in oncological radiotherapy, as well as to present the process of their implementation into the practice of health care institutions.

Key words: clinical audit, standard procedures, commission for procedures and external clinical audits in oncological radiotherapy in Poland.

\section{Quality management system in radiotherapy in the light of regulations applicable in Poland}

\author{
Marta Bogusz-Czerniewicz
}

Training, Scientific Cooperation and Quality Assurance Department, Greater Poland Cancer Centre, Poznan, Poland

\section{Introduction}

Prerequisites and origins of the quality management system in Polish radiotherapy

Quality has become a matter of great importance for many health care institutions, particularly in the context of adverse events and technical failures caused by inaction or negligence in the field of quality assurance [12]. Only then do the important components of quality management, such as sufficient resources (material, human, IT), process monitoring, work standardisation, systematic and planned control and measurements, personnel's competences and responsibilities, a process-oriented approach to actions taken, correct and eligible records (evidence of work done) $[17,18]$ and documentation (instructions and working procedures), become essential for proper functioning of an organisation [16]. Reports of the International Atomic Energy Agency (IAEA) [8, 9, 11, 13-15] also indicate that all radiotherapy-related radiation incidents, especially the most dangerous ones involving fatal casualties, like those in San José ${ }^{1}$ or Goiáni ${ }^{2}$ were directly caused by failures of legislative, organisational and technical nature and, above all, by faults resulting from ignoring elementary requirements and standards set to ensure a set irradiation and radiological protection.

The incident in Białystok [22], which took place in February 2001, was another event to make the state authorities (Ministry of Health, National Atomic Energy Agency) and heads of units applying accelerators and cobalt machines in radiotherapy realise the gravity of the problem and the need to adapt their units to the applicable quality standards with regard to radiological safety. This was especially the case because the obligation to develop and implement quality assurance programmes, understood as a system of actions taken to guar-

1International Atomic Energy Agency (IAEA). Accidental Overexposure of Radiotherapy Patients in San Jose, Costa Rica. Vienna, IAEA, 1998. In July 1997, the authorities of Costa Rica requested the IAEA to assess the radiation accident which occurred in the San Juan de Dios hospital in San José causing 115 patients treated with cobalt-60 in the period from 22 August 1996 to 27 September 1996 to be irradiated with an excessive radiation dose exceeding the set value by around 50-60\%. The accident was directly caused by an error in dose calculations during the calibration of a newly installed source.

International Atomic Energy Agency (IAEA). The Radiological Accident in Goiani. Vienna, IAEA, 1988. In 1985, a private institute of radiotherapy, Instituto Goiano de Radioterapia in Goiânia, Brazil, transferred a cobalt-60 machine to new premises while moving to a new location, but left behind a therapeutic caesium-137 machine unattended in the old abandoned building, without notifying competent authorities of that fact. In consequence, two unauthorised persons, who did not realise what the apparatus served for, considered it to be metal scrap of some value, removed the source from the head of the machine and took it home for further disassembly. They ripped the cover of the source off causing contamination of the environment (including uncontrolled irradiation of a number of people). The remnants of the source were sold to a scrap yard owner who noticed that the material glowed blue in the dark. From the time the source was brought to the scrap yard, many people came to see the phenomenon. Pieces of the source, the size of rice grains, were handed over to members of several families. As a consequence of the whole event, four people died within four weeks following their admission to hospital, and 112,000 people were taken for examination, of whom 249 were found to show various levels of external or in ternal radioactive contamination. 
antee a required level of radiological safety and efficiency of the radiotherapy treatment process, was explicitly set out back in 2000 inter alia in Article 7(2) of the Nuclear Law Act of 29 November 2000, the International Basic Safety Standards for Protection against Ionizing Radiation and for the Safety of Radiation Sources [10], European Council Directive 97/43 and EURATOM Directive 96/29 [6].

27 February 2001 saw a failure of the Neptun 10P accelerator manufactured in 1983 and modernised in 1993. It was caused by a voltage drop. As similar events were reported to have taken place in the past without having any impact on the radiation beam (records in the existing control documentation had not been kept regularly, so there was no reliable and complete evidence to confirm any interim or ongoing control of the irradiator parameters) the treatment was continued when the voltage returned to normal. This resulted in overexposure of radiation due to the absence of an emergency procedure to follow in such a case. This way, five female patients were overexposed. The fourth of them reported a burning sensation to her attending doctor and was referred for additional treatment. Her tests revealed a radiation-induced reaction, which was accounted for by the cumulative effect of earlier therapies. To be certain, the fifth patient was examined before the exposure and no signs of early radiation-induced reaction were found. Then, she was irradiated with a planned fraction dose and re-examined. The patient was found to develop a weakly expressed erythema, a dry skin reaction. For that reason, despite the accelerator's control panel continuing to indicate correct parameters, a decision was taken to switch the apparatus off $[1,2]$.

Following that event, in March 2001, the Quality Assurance Section of the Polish Society of Oncological Radiotherapy organised a conference and workshops for representatives of all Poland's radiotherapy units in order to provide them with recommendations on safe application of radiotherapy and requirements concerning development of therapeutic protocols for radiological procedures.

Similar was the reaction of the Institute for Nuclear Problems (ZDAJ) in Świerk (the manufacturer of Neptun 10P accelerators). In March 2001, all oncological units that used radiotherapy involving accelerators of the types 10P, 10PC, Co-Line and Co-Line PC were provided with a ZDAJ advisory note indicating the need to: (a) follow specific procedures regarding operation, maintenance, adjustment and calibration of medical accelerators; (b) adhere to requirements contained in user manuals and safety instructions for patients and operating staff; (c) document controls of safety systems performed according to the manufacturer-recommended schedule; (d) document all types of technical service, calibration, adjustment and maintenance; (e) limit the operating staff to persons holding certificates issued by the manufacturer; and most importantly (f) implement the Quality Assurance Programme from 1 January 2002 [19].

The National Atomic Energy Agency prepared in turn a checklist, whereby it obliged most units using medical exposure to draw up therapeutic protocols in radiotherapy and equipment quality assurance procedures and instructions, as well as to carry out interim controls of irradiators, measuring equipment, etc.
Unfortunately, the manufacturer indications or the recommendations of the Scientific Society and the National Atomic Energy Agency were not a sufficient instrument to enforce implementation of the quality management system in radiotherapy.

Therefore, the Ministry of Health took the following measures:

1. The National Consultant for Oncological Radiotherapy was ordered to develop a Framework Multiannual Project (to 2010) under the Government Research and Implementation Programme to improve the quality and availability of medical services provided with the use of ionising radiation, including radiological protection of patients and staff, comprising information on the condition of Polish radiotherapy, demands of oncological centres, and staffeducation and training, as well as development plans in the area of radiotherapeutic infrastructure, modernisation and replacement of equipment;

2. An expert team for implementation of the EURATOM Directive $97 / 43$ on health protection of individuals against the dangers of ionising radiation in relation to medical exposure was appointed by the Ordinance of the Minister of Health of 16 November 2001 [38]. The team's efforts led to the development and entry into force of the Ordinance of 24 December 2002 on rules for safe application of ionising radiation for medical exposure and methods for internal controls of compliance with those rules, Journal of Laws, No. 241, item 2098 [25].

The Ministry of Health Ordinance of 24 December 2002 was the first legal measure to introduce the obligation to implement and certify quality management systems (QMS) in health care institutions applying ionising radiation (i.e. in the area of radiotherapy, $\mathrm{X}$-ray diagnostics, and nuclear medicine). Pursuant to that ordinance, health institutions were obliged to develop and implement QMS by 31 December 2004 and to certify it by 31 December 2005.

Furthermore, in 2002 a series of ordinances were adopted [23-35] to regulate many aspects of issues raised in the EURATOM Directive 97/43, EURATOM Directive 90/641 [5] and EURATOM Directive 96/29.

These were developed as Poland's accession to the European Union (May 2004) required Polish law to be harmonised with that of the EU by adopting regulations to constitute a basis for meeting those requirements [23, 26-35] and to create an operating system for their practical implementation into medical practice $[3,4,36]$. The requirements also arose from the Nuclear Law Act adopted by the Polish Parliament on 29 November 2000 [37], whose successive revisions (2004, 2006, 2008 and 2009) required health care institutions performing procedures or treatment involving radiotherapy, nuclear medicine, interventional radiology and $X$-ray diagnostics to undertake actions aimed at preventing medical radiation accidents, perform controls of the radiological equipment and external and internal clinical audits, as well as to implement quality management systems (Article 33(c)(7)). The Nuclear Law Act of 2000, as mentioned before, introduced only the obligation to develop and implement a quality assurance system understood as a programme of actions ensuring the fulfilment of specific radi- 
ological protection and nuclear safety requirements (Article 7(2)).

On 25 August 2005, the Ministry of Health published another ordinance concerning safe application of ionising radiation for all types of medical exposure taking into account the revised requirements of the Nuclear Law Act of 2004. That ordinance regulated in great detail the issue of a quality management system in units using ionising radiation for medical purposes, in particular with regard to rules for keeping medical documentation of the radiation process, external and internal clinical audits, controls of radiological equipment physical parameters, rules of conduct in case of radiological events and rules for implementation and maintenance of QMS in radiotherapy. This implementing act repealed the ordinance of 24 December 2002. Its last revision was adopted quite recently, that is on 18 February 2011. The ordinance introduces some significant changes, the most important of them being the fact of further extension in time (2014) for the obligation to develop model and working procedures.

\section{Aim of the study}

The aim of this study is to review applicable legal regulations with regard to the quality management system in radiotherapy, in particular the regulations concerning mode procedures, appointment of a committee for model procedures and external clinical audits in radiotherapy, and the performance of clinical audits along with the process of their implementation into medical practice of health care units.

\section{Material and methods}

Materials used in this study included the following legal and official documents: Nuclear Law Act of 12 March 2004 (Journal of Laws from 2004, No. 70, item 632); Nuclear Law Act of 24 February 2006 (Journal of Laws from 2006, No. item 378); Ministry of Health Ordinance of 25 August 2005 and 18 February 2011 on safe application of ionising radiation for all types of medical exposure under Article 33(c)(9) of the Act of 29 November 2000 - Nuclear Law (Journal of Laws from 2004, No. 61, item 1689 and No. 173 item 1808); Ministry of Health Ordinance of 2 February 2007 on detailed requirements for the for and content of model and working radiological medical procedures (Journal of Laws from 2007, No. 24, item 161); official letter of the Ministry of Health Public Health Department ref. No. MZ-ZPŚ-078-5762-I/RJ/06 of 15 December 2006.

\section{Results}

The process of transposition of Community directives into the national law and implementation of national regulations into the practice of health care institutions using ionising radiation for medical purposes

The need to establish conditions of safe irradiation was noted in Poland back in 1986, as reflected in the Nuclear Law Act, but it was not until 2002 (that is nearly 16 years later) that the first implementing acts were published to that Act in order to regulate the issue. Thus, the absence of good prac- tice and low awareness of the public caused this important matter to be largely neglected. Only a few of the health care institutions using ionising radiation for medical purposes decided to take quality-oriented actions based mainly on recommendations from scientific associations, such as the AAPM (American Association for Physicists in Medicine) or ESTRO (European Society for Therapeutic Radiation and Oncology), and international organisations such as WHO (World Health Organization), IAEA (International Atomic Energy Agency) or OECI (Organization of European Cancer Institutes).

In 1988, the World Health Organization (WHO) published its first guidelines for implementation of a quality assurance programme in radiotherapy. The WHO programme was the first one to take any actions in this area and became a reference document for development of European guidelines in this respect, which, however, did not happen until nearly ten years later, when such guidelines were finally adopted in 1997: the Council Directive 97/43/EURATOM on health protection of individuals against the dangers of ionising radiation in relation to medical exposure.

The example set by WHO was followed by the International Atomic Energy Agency which, in 1996, published its standards of radiological protection and safety providing for development and implementation of a quality assurance programme in institutions applying radiation for medical purposes. Although it was not a binding instrument, judging from the similarity of the provisions of the Council Directives 96/29/EURATOM and 97/43/EURATOM, published a little later, those acts were partly based on its content.

Directive 97/43/EURATOM is the first European legal act to require health care units applying ionising radiation for medical purposes to implement quality assurance and control programmes and the first one to establish the obligation to conduct clinical audits.

Nevertheless, until 2000 no significant changes were introduced to the Polish legislation as regards legal regulation of the issues related to good and safe practice in applying ionising radiation in radiotherapy.

In 2000, in view of the forthcoming accession to the EU (May 2004), the Polish Nuclear Law Act was revised and the obligation to implement quality assurance programmes in institutions offering ionising radiation for medical purposes was introduced, but exclusively in the field of radiological protection and safety.

Until 2002 (i.e. until the publication of implementing instruments for the Nuclear Law Act of 2000) health care institutions did not have any substantial tools, quality standards (regarding infrastructure, equipment, human resources, therapeutic protocols, documentation, etc.) or guidelines for implementation of quality management programmes or systems.

Poland was not the only country to be confronted with this problem. Most Member States, in spite of their legal obligation to implement the provisions of the above-mentioned directives by 13 May 2000, have not completed the transposition process with regard to practical and detailed guidelines for the quality assurance and control programmes (mainly recommended clinical audits) in radiotherapy, in most cases leaving the task to scientific associations and non-govern- 
mental organisations ${ }^{3}$. After all, the directives set only general directions for safe application of ionising radiation for medical purposes.

In Poland, legislative works were most certainly accelerated by the above-mentioned radiation accident in Białystok (2001). However, in the absence of national guidelines on quality management, most health care institutions followed the model provided by the PN-EN ISO 9001:2001 standard. The general nature and free interpretation of the standard made it possible to apply within any organisational structure, including in units offering ionising radiation for medical purposes, although its industrial terminology often made it difficult for the model proposed to be adapted to the purposes of health service. Therefore, guidelines worked out by scientific associations and international organisations, such as ESTRO, OECI and AAPM, played a vital role in the adaptation process as they were also to a large extent based on the requirements of ISO 9001:2000 and appropriately interpreted for the purposes of health care units.

Eventually, theory gave way to practice and the model was used also in Polish legal acts (Ministry of Health Ordinance of 24 December 2002) establishing basic requirements for quality management systems with regard to medical services involving ionising radiation.

In 2004, the Nuclear Law Act was revised due to inaccuracies and disparities between the existing Nuclear Law Act of 2000 and its implementing instruments and because some of the requirements of the EURATOM Directives had been omitted, e.g. the obligation to implement QMS in institutions applying ionising radiation for medical purposes, perform clinical audits, provide practical and theoretical staff training in radiological practices, establish a national register of equipment emitting ionising radiation, develop written working equipment protocols, draw up standard medical radiological procedures, and specify the process of dose optimisation.

The Nuclear Law Act of 2004 strengthened some other provisions that had been introduced by the 2002 Nuclear Law Act based exclusively on implementing regulations, including rules for radiological protection of non-operating staff, quality management system requirements, conditions for granting authorisations to perform activities involving exposure to ionising radiation, rules for appointing radiological protection officers, rules applicable to supervised and controlled areas, ionising protection dose limits, and rules for applying ionising radiation for medical purposes.

The Nuclear Law Act of 2004 also introduced some new regulations, i.e. the obligation to obtain permission from the Minister of Health to perform activities involving medical ex- posure to ionising radiation by providing medical services in the area of oncological radiotherapy, the appointment by the Minister of Health of the Committee for Procedures and External Clinical Audits in the areas of Oncological Radiotherapy, Nuclear Medicine, Radiology - Diagnostic Imaging and Interventional Radiology, and the establishment by the Minister of Health of the National Centre of Radiological Protection in Health Care. Already regulated are the issues connected with the Minister of Health's authorisation for provision of medical services in oncological radiotherapy and the establishment by the Ministry of Health of the National Centre of Radiological Protection in Health Care, while the other provisions of the Act, although introduced under implementing legal instruments, remain 'dead'.

On 25 August 2005, taking into account the revised provisions of the Nuclear Law Act of 2004, the Ordinance on rules of safe application of ionising radiation for all types of medical exposure was published with the intention to address the inaccuracies and disparities contained in the Ordinance of 24 December 2002.

The fact is that most provisions of the Ordinance of 24 December 2002 concerning requirements for quality management and control systems not only failed to be used in the everyday practice of institutions applying medical exposure (which applied inter alia to clinical audits; internal and external audits of procedures under the quality control system; implementation of the QMSR document [Quality Management System in Radiotherapy]; validation of therapy plans by two doctors; double check on irradiation sheets made once a week by two doctors), but were also incorrectly formulated in the context of the theory of organisation and management. Irregularities included the following:

a) the Ordinance provided for development of a document under the name of Quality Management System in Radiotherapy. However, a system is not a document but a set of correlated or interacting elements (processes). Documents are procedures and instructions. Records are the evidence of our daily work, etc. A document of this type, determining goals and tasks of a radiation facility, radiation therapy procedures and stages, forms and methods of their supervision, and responsibilities of persons in charge of their implementation, should be called a Quality Book.

b) The Ordinance provided for the obligation to draw up procedures in the form of instructions. A procedure is a way to carry out an action or a process (e.g. treatment) specifying where, by whom, when and why an action is performed, e.g. the conformal radiotherapy procedure or internal audit procedure. An instruction is precise information or guidance

\footnotetext{
3 Under the project Clinical AUD Contract N TREN/07/NUCL/S07.71512 - European Guidance on Clinical Audit for Medical Exposure 2007-2009, financed by the European Commission's funds, a survey was conducted with 67 representatives of European societies of oncological radiotherapy. The objective of the survey was to check the degree of compliance of national laws in particular Member States with the requirements of the Council Directive 97/43/EURATOM and the degree of implementation and maintenance of quality management systems in radiotherapy. The responses obtained showed that most of the countries had only recently (within the last 2-3 years) regulated issues related to conditions for applying ionising radiation for medical purposes by implementing the provisions of Directive 97/43/EURATOM. While most of the countries have generally implemented the requirements of the directive, such aspects as the scope of clinical audit, the method of audit, composition of an auditing team, a QMS model in radiotherapy, the scope of systemic documentation, etc. are yet to be incorporated into the operating practice of institutions applying radiotherapy. Most of the respondents confirmed that clinical audits, if performed, had not been in any way decisive as to authorisations to provide radiotherapeutic medical services. The responsibility for regular controls of radiotherapy institutions is still held by public authorities. In some Member States (incl. Poland the Czech Republic, the Netherlands) legal regulations are complemented with recommendations from scientific associations, the academic community or accreditation institutions. Most European health care institutions have implemented quality management systems based on the requirements of ISO 9001:2000. Implementation of the directive's provisions is still in progress and in most cases managed by working groups appointed by respective Ministries of Health or National Atomic Energy Agencies.
} 
on how to perform a specific action, determining the way in which a specific action should be done, e.g. equipment operating instruction or instruction for room decontamination following radioactive pollution.

c) According to the Ordinance the QMSR should be updated. In fact it is the documentation that should be updated, whereas the system should be improved.

Furthermore, system requirements were set out selectively, with focus limited to certain aspects of a radiotherapy unit and a radiotherapy procedure. The requirements were not homogeneous in nature and formed a set of selected guidelines concerning mainly therapy planning and performing rather than indicating particular organisational, clinical and physico-technical issues.

Most Polish radiotherapy units have performed neither the clinical audits required by the Ordinance (clinical audits being the only concept defined by the Ordinance) nor external and internal quality control system audits. The main reason for that is the lack of practical and formal instructions as to methods of such audits. No transition period was set for implementation of the audits, and no rules provided for their frequency or composition of auditing teams (Minister of Health's responsibility), reporting, or legal and formal consequences in case of a failure to perform audits or non-conformities found during such audits. Many of these issues are yet to be resolved.

In view of the above, units that had implemented and certified QMS had their internal and external audits on a periodical basis only, as required by relevant certification bodies (e.g. LRQA, TÜV, DEKRA, PCBC).

Most institutions applying ionising radiation for medical purposes, in order to meet the requirement laid down in the Ordinance in question, have implemented and certified a QMS based on PN-EN ISO 9001:2001 pursuant to §9.1. of the Ordinance rather than the Radiotherapy Management and Quality Control System pursuant to Annex 13 thereto.

The Ordinance of 28 August 2005 did regulate some matters related to safe application of ionising radiation in medicine, organisation of work in units offering ionising radiation therapy, as well as implementation and maintenance of a quality management system in radiotherapy, but as was the case with earlier versions, many of its provisions remained 'dead', which gave rise to the need for yet another revision.

It needs to be pointed out that reports of international organisations, such as WHO, IAEA, OECI and EORTC, have played a very important role in raising awareness on radiotherapy quality and prompting European laws in the area of ionising radiation for medical exposure.

In addition, owing to Poland's accession to the EU and the transposition of EU regulations into the Polish legal system, the national laws, unusually detailed as they are, correspond to the EU legislation, although it had taken a long time (20 years) and much work for them to be proposed, revised and adopted.

The legal regulations applicable as of March 2010 set out very detailed requirements for a quality management system, rules for appointment by the Minister of Health of the Committee for Procedures and External Clinical Audits in the areas of Oncological Radiotherapy, Nuclear Medicine, Radiology - Diagnostic Imaging and Interventional Radiology, and the establishment by the Minister of Health of the National Centre for Radiological Protection in Health Care (http://www.kcor.gov.pl/), as well as imposing the requirement to perform internal clinical audits not later than by December 2006 and to have an external clinical audit performed by December 2009. Not all of those regulations, however, have been applied in practice:

1. Members of the Committee for Procedures and External Clinical Audits were appointed four years after the publication of the Ordinance setting out the obligation to form such a committee, that is on 21 January 2009, probably following an NIK (Supreme Control Camber) control of the National Cancer Control Programme for 2006-2015 which revealed the non-compliance. The task of appointing the Committee and setting a schedule of its actions was assigned by the Minister of Health to the Chief Sanitary Inspector (CSI).

2. As a result, the Committee's assignment of drawing up model radiological procedures for legitimate medical exposures, which in turn form the basis for working radiological procedures to be prepared by health care institutions, has not been completed so far. What is more, the revision of the Ministry of Health Ordinance of 18 February 2011 on rules of safe application of ionising radiation for all types of medical exposures provides for this objective to be achieved by 31 December 2014, thus extending its completion by a further four years. According to the Committee, it was possible only for procedures of utmost importance for patients' safety to be developed by the end of 2010 (four of them have been developed so far: regarding whole body irradiation, intraoperative brachytherapy, intraoperative radiation therapy, and total skin electron radiotherapy), mainly because of the obligation to begin clinical audits by 2011 (which are anyway delayed by three years, as the Minister of Health Ordinance of 2005 provides for them to be carried out by 2009).

3. Those circumstances have so far prevented internal and external clinical audits from being performed in health care institutions, as clinical audits mainly involve assessment of radiological working procedures in terms of their compliance with model procedures. The aim of an audit is to evaluate/review an institution (radiological equipment and medical procedures it uses) based on accepted rules and standards derived from international, national and local regulations, as well as on guidelines from scientific associations.

With practical guidelines on the quality management system in radiotherapy absent for many years (since 2002), most institutions applying ionising radiation for medical purposes have implemented and certified QMS based on the PNEN ISO 9001:2000 standard (current PN-EN ISO 9001:2009), including appropriate, self-developed basic and auxiliary procedures, and thus conduct their QMS internal and external audits in line with that standard.

In conclusion: if all the provisions of applicable implementing acts are put into effect and the Ministry of Health provides the Committee for Procedures and External Clinical Audits and health care institutions with appropriate measures and tools to implement them, such acts may be considered to be a good source not only of quality standards but also of practical solutions for quality assurance and control in radiotherapy. Worth underlining is also the fact that none of the EU countries has legal regulations at this level of de- 
tail. Most regulated matters fall into the scope of so-called rules of good practice published by scientific associations in the form of recommendations. The role of the state, following the example of the EU, is to adopt framework regulations and ensure logistic and financial support for scientific associations or expert groups responsible for developing adequate guidelines.

In 2009, the European Commission supplemented the Directive 97/43/EURATOM with Radiation Protection No. 159 European Commission Guidelines on Clinical Audit for Medical Radiological Practice (diagnostic imaging, nuclear medicine and radiotherapy) Directorate-General for Energy and Transport Directorate H - Nuclear Energy Unit H.4 - Radiation Protection 2009. The task of developing the guidelines was contracted by the European Commission through a tender procedure and financed by EC funds under the contract N TREN/07/NUCL/S07. 71512. The contract was awarded to an interdisciplinary team of international experts:

- Hannu Järvinen - project coordinator from the Radiation and Nuclear Safety Authority (STUK), Helsinki, Finland

- Seppo Soimakallio, Tuija Wigren, Tiit Kööbi from Tampere University Hospital (TAUH), Tampere, Finland

- Julian Malicki, Hana Stankusova, Mary Coffey, Marta BoguszCzerniewicz representing the European Society for Therapeutic Radiology and Oncology (ESTRO), Brussels, Belgium

- Johannes Nischelsky representing the General Medical Council Westfalia-Lippe, Münster/Westfalen, Germany

- Andrew Hilson representing BNMS, London, United Kingdom

- Gendrutis Morkünas from the Radiation Protection Centre, Vilnius, Lithuania, and

- Eliseo Vano (Spain), Adrian Dixon (UK), András Vargha (Hungary), Pierre Scalliet (Belgium), Vincenza Viti (Italy), Päivi Wood (Finland), Lorenzo Maffioli (Italy), Joanna Izewska, IAEA (Austria).

The solution proposed by the European Commission is a good example of how the mandate to define rules of good practice in a specific area can be delegated to scientific associations/expert teams.

A similar pattern was followed at the national level where the task of developing model procedures and national guidelines for clinical audits was assigned to the Committee for Procedures and External Clinical Audits made up by Polish experts in radiotherapy, nuclear medicine and diagnostic imaging. By a decision of the Minister of Health, works of the Committee are directly coordinated and supervised in terms of organisation and administration by the National Centre for Radiological Protection (NCRP) in Health Care. The works, although quite recently started - in 2010 committee members were appointed, in 2011 guidelines for external audits were drawn up, and conditions for development of model procedures were set - should not be postponed as is proposed by the latest revision of the Ordinance of 18 February 2011 on rules for safe application of ionising radiation for medical purposes. Prolonging the implementation of measures aimed at developing model procedures and, consequently, institutional (working) procedures by a further four years (until 2014) is by no means justified, particularly considering that the guidelines ordered by the NCRP have already been completed and the deadline for internal and external clinical audits has remained unchanged (in the light of applicable legal regulations, health care institutions should have conducted their internal clinical audits by December 2006, and external and dosimetric audits by December 2009).

\section{References}

1. Bogusz-Czerniewicz M. System Zarządzania Jakością w Radioterapii, Wydawnictwo Naukowe Uniwersytetu Medycznego w Poznaniu, Poznań 2010.

2. Bogusz-Osawa M, Kosicka G. Istota wdrożenia programu zapewnienia jakości bezpiecznego napromieniania podczas radioterapii megawoltowej. Zdr i Zarz 2002; 4: 67-71.

3. Bogusz-Osawa M, Osawa T. The influence of changes in the Polish legislation on the quality and the cost of radiotherapy. The Biennial ESTRO Meeting on the Physics and Radiation Technology for Clinical Radiotherapy; 2005 Sept 24-29; Lisboa, Portugal. Radiother Oncol 2005; 76: S33-4.

4. Bogusz-Osawa M, Świeżewski A, Osawa T, et al. Wpływ zmian legislacyjnych na koszty i jakość w radioterapii. W: Głowacka MD [red.]. Profesjonalizm w Ochronie Zdrowia, Wyd.1. Wydawnictwo Wyższej Szkoły Komunikacji i Zarządzania; Poznań, 2005: 103-12.

5. Dyrektywa Rady 90/641/Euratom z dnia 04.12.1990 w sprawie praktycznej ochrony pracowników zewnętrznych, narażonych na promieniowanie jonizujące podczas pracy na terenie kontrolowanym. Dziennik Urzędowy L-349 z 0513/12/90.

6. Dyrektywa Rady 96/29/EURATOM z dnia 13 maja 1996 ustanawiająca podstawowe normy bezpieczeństwa w zakresie ochrony zdrowia pracowników i ogółu społeczeństwa przed zagrożeniami wynikającymi z promieniowania jonizującego. Dziennik Urzędowy L-159 z 29/06/96.

7. Dyrektywa Rady 97/43/Euratom z dnia 30.06.1997 w sprawie ochrony zdrowia osób fizycznych przed niebezpieczeństwem wynikającym z promieniowania jonizującego związanego z badaniami medycznymi oraz uchylająca dyrektywę 84/466/Euratom. Dziennik Urzędowy L-180 z 09/07/97.

8. International Atomic Energy Agency (IAEA). Accidental Overexposure of Radiotherapy Patients in Bialystok. Vienna, IAEA, 2004.

9. International Atomic Energy Agency (IAEA). Accidental Overexposure of Radiotherapy Patients in San Jose, Costa Rica. Vienna, IAEA, 1998.

10. International Atomic Energy Agency (IAEA). International Basic Safety Standards for Protection against Ionizing Radiation and for the Safety of Radiation Sources, Safety series No. 115. Vienna, IAEA, 1996.

11. International Atomic Energy Agency (IAEA). Investigation of accidental exposure of radiotherapy patients in Panama. Vienna, IAEA, 2001.

12. International Atomic Energy Agency (IAEA). Safety Report Series No. 17: Lessons learned from accidental exposures in radiotherapy. Vienna, IAEA, 2000.

13. International Atomic Energy Agency (IAEA). The Radiological Accident in Gilan. Vienna, IAEA, 2002

14. International Atomic Energy Agency (IAEA). The Radiological Accident in Goiani. Vienna, IAEA, 1988.

15. International Atomic Energy Agency (IAEA). The Radiological Accident in Samut Prakarn, Vienna, IAEA, 2002.

16. Karzmark CJ. Procedure and operator error aspects of radiation accidents in radiotherapy. Int J Radiat Oncol Biol Phys, 1987; 12: 1599-602.

17. Luenens G, Verstraete J, Van den Bogaert W, et al. Human errors in data transfer during the preparation and delivery of radiation treatment affecting the final result: "garbage in, garbage out". Radiother Oncol, 1992; 23: 217-22.

18. Malicki J, Litoborski M, Kierzkowski J, et al. How the implementation of in-vivo dosimetry protocol improved the dose delivery accuracy in head and neck radiotherapy. Neoplasma, 2004; 51: 155-8.

19. Notatka doradcza Dyrektora ZDAJ IPJ Jacka Pracza z dnia 12.03.2001 r.

20. Pismo urzędowe z Ministerstwa Zdrowia Departamentu Zdrowia Publicznego MZ-ZPŚ-078-5762-I/RJ/06 z 15.12.2006 r.

21. Projekt Rozporządzenia Ministra Zdrowia z dnia 9.02.2009 r. w sprawie warunków bezpiecznego stosowania promieniowania jonizującego dla wszystkich rodzajów ekspozycji medycznej.

22. Protokół Kontroli Doraźnej Białostockiego Ośrodka Onkologicznego im. M. Skłodowskiej-Curie, przeprowadzonej w dniu 01.06.2001 r. Au- 
torka książki była członkiem Specjalnej Komisji Ministerstwa Zdrowia powołanej w celu kontroli doraźnej białostockiego ośrod ka onkologicznego - Białystok, 1 czerwca 2001 r.

23. Rozporządzenie Ministra Pracy i Polityki Społecznej z dnia 29.11.2002 r. w sprawie najwyższych dopuszczalnych stężeń i natężeń czynników szkodliwych dla zdrowia w środowisku pracy. Dz. U. Nr 217 poz. 1833

24. Rozporządzenie Ministra Zdrowia z dnia 24.12.2002 r. w sprawie warunków bezpiecznego stosowania promieniowania jonizującego w celach medycznych oraz sposobu wykonywania kontroli wewnętrznej nad przestrzeganiem tych warunków. Dz. U. Nr 241, poz. 2098.

25. Rozporządzenie Ministra Zdrowia z dnia 25.08.2005 w sprawie warunków bezpiecznego stosowania promieniowania jonizującego dla wszystkich rodzajów ekspozycji medycznej, na podstawie art. 33c ust. 9 ustawy z dnia 29.11.2000 - Prawo Atomowe Dz. U. z 2004 r. Nr 61, poz. 1689 i Nr 173 poz. 1808.

26. Rozporządzenie Ministra Zdrowia z dnia 2 lutego 2007 r. w sprawie szczegółowych wymagań dotyczących formy i treści wzorcowych roboczych medycznych procedur radiologicznych Dz. U. 2007, nr 24, poz. 161.

27. Rozporządzenie Rady Ministrów z dnia 28.05.2002 r. w sprawie dawek granicznych promieniowania jonizującego 03.08.2002. Dz.U. Nr 111, poz. 969 z późn. zm. z dnia 18.01.2005 r.

28. Rozporządzenie Rady Ministrów z dnia 06.08.2002 r. w sprawie pod stawowych wymagań dotyczących terenów kontrolowanych i nadzorowanych. Dz.U. Nr 138, poz. 1161.

29. Rozporzadzenie Rady Ministrów z dnia 06.08.2002 r. w sprawie rodzajów stanowisk mających istotne znaczenie dla zapewnienia bez pieczeństwa jądrowego i ochrony radiologicznej szczegółowych warunków i trybu nadawania uprawnień dla osób, które mogą być zatrudnione na tych stanowiskach. Dz. U. Nr 145 poz. 1217, znowelizowane 18.01.2005 r., Dz. U. Nr 21 poz. 176.

30. Rozporządzenie Rady Ministrów z dnia 05.11.2002 r. w sprawie wymagań dotyczących rejestracji dawek indywidualnych. Dz. U. Nr 207, poz. 1753.

31. Rozporzadzenie Rady Ministrów z dnia 03.12.2002 r. w sprawie doku mentów wymaganych przy składaniu wniosku o wydanie zezwole nia na wykonywanie działalności związanej z narażeniem na działanie promieniowania jonizującego albo przy zgłoszeniu wykonywania tej działalności. Dz. U. Nr 220, poz. 1851 z późn. zm. z dnia 27.04.2004 r.

32. Rozporządzenie Rady Ministrów z dnia 03.12.2002 r. w sprawie odpadów promieniotwórczych i wypalonego paliwa jądrowego, Dz.U. Nr 230, poz. 1925.

33. Rozporządzenie Rady Ministrów z dnia 17.12.2002 r. w sprawie szczegółowych warunków bezpiecznej pracy ze źródłami promieniowania jonizującego. Dz. U. Nr 239 poz. 2029.

34. Rozporządzenie Rady Ministrów z dnia 23.12.2002 r. w sprawie wymagań dotyczących sprzętu dozymetrycznego Dz. U. Nr 239, poz. 2032

35. Rozporzadzenie Rady Ministrów z dn. 18.01.2005 r. w sprawie planów postępowania awaryjnego w przypadku zdarzeń radiacyjnych. Dz.U. Nr 20 poz. 169.

36. Teunen D., The European Directive on health protection of individuals against the dangers of ionizing radiation in relation to medical exposure (97/43/Euratom). J Radiol Prot 1998; 18: 133-7.

37. Ustawa Prawo Atomowe z dnia 29.11.2000 r. Dz. U. z 2001 r. Nr 3 poz. 18.

38. Zarządzenie Ministra Zdrowia z dnia 16 listopada 2001 r. w sprawie powołania Zespołu do spraw implementowania Dyrektywy 97/43/Euratom w zakresie ochrony osób przed zagrożeniem związanym z promieniowaniem jonizującym stosowanym w celach medycznych, Dz. Urz. MZ Nr 11, poz. 72, z późn. zm. (z dnia 22 lipca 2002 r. Dz.Urz. MZ Nr 3 poz. 9, a także z dnia 6 lutego 2004 r. Dz. Urz. MZ. Nr 2 poz. 14)

\section{Address for correspondence}

dr n med. Marta Bogusz-Czerniewicz

Training, Scientific Cooperation and Quality Assurance Department

Greater Poland Cancer Centre

Garbary 15

61-866 Poznań, Poland

e-mail: marta.bogusz@wco.pl

Submitted: $\quad 24.06 .2011$

Accepted: $\quad 2.12 .2011$ 